\title{
Impact of curative parathyroidectomy on left ventricular functions assessed with 2D ECHO and MUGA study
}

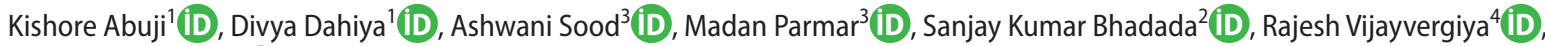
Arunanshu Behera'[i]

1 Department of General Surgery, Postgraduate Institute of Medical Education and Research (PGIMER), Chandigarh, India

2 Department of Endocrinology, Postgraduate Institute of Medical Education and Research (PGIMER), Chandigarh, India

${ }^{3}$ Department of Nuclear Medicine, Postgraduate Institute of Medical Education and Research (PGIMER), Chandigarh, India

${ }^{4}$ Department of Cardiology, Postgraduate Institute of Medical Education and Research (PGIMER), Chandigarh, India

\section{ABSTRACT}

Objective: Primary hyperparathyroidism (PHPT) is associated with increased cardiovascular morbidity and mortality with inconsistent results on the reversibility of cardiovascular changes after parathyroidectomy (PTX). The present study was undertaken to evaluate both structural and functional cardiac changes and their reversal after PTx in patients with PHPT.

Material and Methods: Thirty patients of symptomatic PHPT without cardiovascular risk factors were evaluated prospectively by means of 2D echocardiography (ECHO) and Multigated Acquisition (MUGA) study before surgery and six months after curative parahyroidectomy.

Results: Nine of 30 patients had hypertension which improved in two after PTx ( $p 0.20)$. Two patients had left ventricle hypertrophy on $2 \mathrm{D}$ ECHO preoperatively which improved after PTx $(p<0.001)$. Left ventricular ejection fraction (LVEF) did not show significant change before and after PTx on 2D ECHO. Nine out of 30 patients had hypertension which improved in two after PTx ( $p$ 0.20). Two patients with left ventricle hypertrophy on 2D ECHO preoperatively improved after PTx $(p<0.001)$. Left ventricular ejection fraction (EF) did not depict significant change before and after PTx on 2D ECHO. Whereas, four out of six patients with preoperative EF $<50 \%$ representing systolic dysfunction on MUGA study showed improvement after PTx. On 2D ECHO, eight patients depicted diastolic dysfunction which improved in six patients after curative surgery $(p=0.07)$. However, on MUGA study, 13 patients presented with tTPF $>180 \mathrm{~ms}$ indicating diastolic dysfunction, of which ten showed improvement after PTx $(p=0.007)$.

Conclusion: The present study analyzed preoperative and postoperative cardiac function using both 2D ECHO and MUGA study. MUGA study provided a more objective assessment of the cardiac function by determining left ventricular ejection fraction and diastolic dysfunction.

Keywords: Muga study, primary hyperparathyroidism, left ventricular dysfunction, 2D ECHO, parathyroidectomy, cardiac manifestations

Cite this article as: Abuji K, Dahiya D, Sood A, Parmar M, Bhadada SK, Vijayvergiya R, et al. Impact of curative parathy roidectomy on left ventricular functions assessed with $2 \mathrm{D}$ ECHO and MUGA study. Turk J Surg 2021; 37 (4): 336-341.

\section{Corresponding Author}

Divya Dahiya

E-mail: dahiyadivya30@gmail.com

Received: 02.01 .2021

Accepted: 12.08 .202

Available Online Date: 31.12 .202

- Copyright 2021 by Turkish Surgical Society Available online at www.turkjsurg.com

DOI: 10.47717/turkjsurg.2021.5167

\section{INTRODUCTION}

Primary hyperparathyroidism (PHPT) is the third most common endocrine disorder characterized by raised serum calcium and parathyroid hormone (PTH) levels; and is mainly asymptomatic at the time of diagnosis in western countries $(1,2)$. However, in India, most of the PHPT patients are symptomatic with nephrolithiasis, osteoporosis, cardiovascular disorders and other symptoms related to hypercalcemia (3).

Hypercalcemic PHPT is associated with increased cardiovascular morbidity and mortality as elevated levels of both PTH and calcium have direct positive ionotropic effect on the heart (4). Patients with PHPT may have both structural and functional cardiovascular changes like increased left ventricular mass index and impaired left ventricular function (diastolic dysfunction, abnormal left ventricular ejection fraction). There are conflicting reports for the clinical significance of cardiovascular co-morbidities in PHPT as according to the $4^{\text {th }}$ international guidelines for the management of asymptomatic PHPT, cardiovascular involvement is not an indication for parathyroidectomy (PTx) (5). In addition; there are inconsistent results on the reversibility of cardiovascular changes after PTx (6-8).

Cardiovascular changes in PHPT have been assessed by 2D echocardiography (2D $\mathrm{ECHO}$ ) in various studies. Although, $2 \mathrm{D} \mathrm{ECHO}$ is easy to perform and does not impart any radiation to the patient, the procedure is highly operator-dependent and has several limitations, especially in obese patients. Multigated Acquisition (MUGA) study is a noninvasive established modality for the evaluation of left ventricle systolic and diastolic function. It is more specific in detecting regional wall motion 
abnormality with a specificity of more than $90 \%$ even in obese patients. It has been used in patients with known or suspected coronary heart disease, lesions in heart valves, congestive heart failure, patients taking cardiotoxic drugs to detect abnormalities in ventricular wall motion or systolic dysfunction. Therefore, the aim of this study was to evaluate both structural and functional cardiac changes in patients of PHPT without cardiovascular risk factors, using 2D ECHO and MUGA study. The study also aimed to assess any improvement in these parameters after curative PTX.

\section{MATERIAL and METHODS}

This prospective study was conducted in the department of General Surgery and department of Nuclear Medicine from July $1^{\text {st }}, 2018$ to December $31^{\text {st }}, 2019$. Thirty patients who underwent curative PTx for PHPT were included after obtaining ethics approval from the institute (INT/IEC/2019/001000). A written informed consent was taken from all patients. Patients with pre-existing cardiac disease and a body mass index of $>28 \mathrm{~kg} /$ $\mathrm{m}^{2}$ were excluded from the study.

All patients underwent 2D echocardiography and MUGA study prior to surgery and six months after PTx. Echocardiography was performed using Philips EPIQ 7 ultrasound machine by an experienced cardiologist. On 2D ECHO, mitral and aortic valve calcification, left ventricular hypertrophy $(\mathrm{LVH})$, left ventricular ejection fraction (EF), inter ventricular septal thickness (IVST), and posterior wall thickness (PWT) were assessed. LVH was diagnosed using IVST and PWT on 2D ECHO; 9-11 mm thickness was considered normal, 12-13 mm was considered as mild LVH, 14-17 mm was considered as moderate LVH and $>17 \mathrm{~mm}$ was considered as severe LVH. Systolic dysfunction was considered if $\mathrm{EF}$ was $<50 \%$. Diastolic dysfunction was diagnosed on 2D $\mathrm{ECHO}$ by measuring early filling to atrial filling ratio (E/A).

\section{MUGA Study Protocol}

Patients were given potassium perchlorate salt $(10 \mathrm{mg} / \mathrm{kg}$ body weight) orally with intravenous injection of $1 \mathrm{ml}$ of DTPA. After a waiting period of 20 minutes, patients were injected with $20 \mathrm{mCi}$ of ${ }^{99 \mathrm{~m}} \mathrm{Tc}$ sodium pertechnetate. Imaging was obtained with a gamma camera after 20 minutes of injection to achieve the equilibrium. ECG gating was carried out using $\mathrm{R}$ wave as a trigger. The cardiac cycle was divided into 32 frames. Scan was acquired in the left anterior oblique with best septal view (in which the interventricular septum is best visualized delineating both right and left ventricular blood pool). The review and analysis of the data were undertaken both by qualitative and quantitative modes with regard to the ventricular contraction and wall motion. After initial visual assessment, a region of interest (ROI) was drawn around the left ventricular blood pool with background $\mathrm{ROI}$ to generate the generated left ventricular ejection fraction, peak filling rate (PFR) and time to peak filling (tTPF) with the aid of software. PFR was expressed in EDV/s, and tPFR was expressed in ms. Diastolic dysfunction was assessed on MUGA study by measuring PFR and tTPF. Diastolic dysfunction was considered if PFR was $<2.5 \mathrm{EDV} / \mathrm{s}$ and tTPF was $>180 \mathrm{~ms}$.

Parathyroidectomy was considered curative if patient's serum calcium and PTH levels stayed in the normal range six months after PTX.

\section{Stastistical Analysis}

Data was analyzed using SPSS (version 26). All quantitative variables were estimated using measures of mean, median, standard deviation (SD) and interquartile range (IQR). Normality of data was checked by measures of skewness and Kolmogorov Smirnov tests of normality. For normally distributed data, mean was compared using Student's T-Test. For skewed data, Mann-Whitney test was applied. Categorical variables were described as frequencies and proportions. Proportions were compared using Chi square or Fisher's exact test. All $p$ values were considered significant when they were $\leq 0.05$.

\section{RESULTS}

Thirty PHPT patients with a single gland disease were enrolled in the study. Mean age was determined to be 49.87 years (49.8 \pm 10.9 ), in the range of $25-73$ years. In this group, only three were males while 27 were female patients. All patients of PHPT were symptomatic for the disease; majority had nephrolithiasis (80\%) followed by bone disease (66.6\%) (Table 1). Preoperative median serum PTH was 1018 pg/ml (1 ${ }^{\text {st }}$ IQR 169, $3^{\text {rd }}$ IQR 1514), median serum calcium was $11.88 \mathrm{mg} \%$ (1 $^{\text {st }} \mathrm{IQR} 11.03,3^{\text {rd }} \mathrm{IQR}$ 13.42) and median vitamin-D was $28.13 \mathrm{ng} / \mathrm{ml}$. All underwent curative PTx with median serum PTH of $33.5 \mathrm{pg} / \mathrm{ml}\left(1^{\text {st }}\right.$ IQR 23, $3^{\text {rd }}$ IQR 41) and median serum calcium of $9.15 \mathrm{mg} \%\left(1^{\text {st }}\right.$ IQR 8.9 , $3^{\text {rd }}$ IQR 9.7) after six months of PTx (Table 2).

Table 1. Demographic profile of patients of Primary Hyperparathyroidism $(n=30)$

\begin{tabular}{|c|c|}
\hline Age (years) & $49.87+10.9$ \\
\hline Sex (M:F) & $3: 27$ \\
\hline \multicolumn{2}{|l|}{ Symptoms (n,\%) } \\
\hline -Renal stones & $24(80)$ \\
\hline -Bone pain & $20(66.6)$ \\
\hline -Fractures & $06(20)$ \\
\hline -Pancreatitis & $01(3.3)$ \\
\hline -Acid peptic disease & $01(3.3)$ \\
\hline -Behavioral problems & $01(3.3)$ \\
\hline \multicolumn{2}{|l|}{ Serum PTH (pg/ml) } \\
\hline Median $\left(1^{\text {st }}\left|\mathrm{QR}, 3^{\text {rd }}\right| \mathrm{QR}\right)$ & $1018(169,1514)$ \\
\hline \multicolumn{2}{|l|}{ Serum Calcium (mg/dl) } \\
\hline Median ( $\left.1^{\text {st }}\left|\mathrm{QR}, 3^{\text {rd }}\right| \mathrm{QR}\right)$ & $11.88(11.03,13.42)$ \\
\hline \multicolumn{2}{|l|}{ Vitamin-D (ng/ml) } \\
\hline Median (1 $\left.1^{\text {st }}\left|\mathrm{QR}, 3^{\text {rd }}\right| \mathrm{QR}\right)$ & $28.13(15.35,44.5)$ \\
\hline
\end{tabular}


Table 2. Pre-and six month post-operative biochemical, 2D ECHO and MUGA study parameters in primary hyperparathyroidism patients ( $\mathrm{n}$ 30)

\begin{tabular}{|c|c|c|c|}
\hline & Pre-operative & Post-operative & p \\
\hline $\begin{array}{l}\text { Serum PTH }(\mathbf{p g} / \mathbf{m l}) \\
\text { Median }\left(1^{\text {st }}\left|\mathrm{QR}, 3^{\text {rd }}\right| \mathrm{QR}\right)\end{array}$ & $1018(169,1514)$ & $33.5(23,41)$ & $<0.0001$ \\
\hline $\begin{array}{l}\text { Serum calcium (mg/dL) } \\
\text { Median }\left(1^{\text {st }}\left|\mathrm{QR}, 3^{\text {rd }}\right| \mathrm{QR}\right)\end{array}$ & $11.88(11.03,13.42)$ & $9.15(8.9,9.7)$ & $<0.001$ \\
\hline Hypertension (n) & $09 / 30$ & $07 / 30$ & 0.20 \\
\hline 2D ECHO & & & Fischer's Exact Value \\
\hline EF (\%) & $0 / 30$ & $0 / 30$ & - \\
\hline LVH (n) & $02 / 30$ & $0 / 30$ & 0.49 \\
\hline Mitral valve calcification & $03 / 30$ & $03 / 30$ & - \\
\hline Aortic valve calcification & $04 / 30$ & $04 / 30$ & - \\
\hline Diastolic dysfunction atrial filling ratio (E/A) & $08 / 30$ & $02 / 30$ & 0.07 \\
\hline \multicolumn{4}{|l|}{ MUGA study } \\
\hline & & & Fischer's Exact Value \\
\hline EF (\%) & $06 / 30$ & $02 / 30$ & 0.25 \\
\hline tTPF (ms) & $13 / 30$ & $03 / 30$ & 0.007 \\
\hline
\end{tabular}

Nine out of 30 patients of PHPT were hypertensive and were prescribed anti-hypertensive medications. After curative PTx, hypertension improved in two of these nine patients on follow up at six months, and they did not require anti-hypertensive medications subsequently $(p=0.20)$ (Table 2$)$.

\section{Left Ventricular Hypertrophy and Valvular Calcification}

On 2D ECHO, two of 30 patients had moderate LVH with wall thickness of $14 \mathrm{~mm}$ (6.7\%). LVH improved in both these patients post operatively at six months ( $p$ 0.49) with decrease in left ventricular wall thickness to $10 \mathrm{~mm}$. Valvular calcifications were present in seven patients (23.3\%); four patients depicted aortic and three developed mitral valve calcifications. There was no change in valvular calcification after PTx (Table 2).

\section{Systolic Dysfunction}

On 2D ECHO, no patient had systolic dysfunction (EF <50\%). Preoperative mean EF was $55.8 \pm 2.9 \%$ and six months after PTx mean EF was $55.4 \pm 3.8 \%$ without any significant difference ( $p=$ 0.379) (Table 2). However, on MUGA study, six patients had EF $<50 \%$ representing systolic dysfunction. After curative PTX, EF was improved in four of these six patients $(p=0.25)$.

\section{Diastolic Dysfunction}

On 2D ECHO, eight patients had diastolic dysfunction which improved in six of them after curative surgery ( $p$ 0.07). However, on MUGA study, mean PFR before and after six months of PTx was $3.48 \pm 0.82$ and $3.18 \pm 0.74$ respectively $(p=0.058)$. PFR was in the normal range both pre- and post-operatively. Preoperative mean tTPF was $171 \pm 41.75 \mathrm{~ms}$ and after six months post-operatively mean tTPF was $156.63 \pm 34.23$ ms (Table 2).
Thirteen of 30 patients depicted tTPF >180 ms indicative of diastolic dysfunction and ten of these patients presented with improvement in tTPF to $<180$ ms after six months of PTx; signifying improvement in diastolic function after curative surgery $(p=0.007)$.

When preoperative serum calcium and PTH levels were compared among patients with or without systolic and diastolic dysfunction, it was observed that there was no correlation of left ventricle dysfunction with serum PTH and serum calcium levels (Table 3).

\section{DISCUSSION}

In this study, pre- and post-operative cardiac function in PHPT patients using both 2D ECHO and MUGA study were compared. MUGA study provided an enhanced objective assessment of cardiac function by determining left ventricular ejection fraction and diastolic dysfunction; which also showed improvement in left ventricular function after PTx. Presence of systolic and diastolic dysfunction and their reversal also depends upon the duration of hypercalcemia, the level of serum PTH, and whether patient was symptomatic or asymptomatic. However, association of raised serum calcium and PTH levels with left ventricular dysfunction could not be established. All PHPT patients in this study were symptomatic which may be the reason that the cardiovascular changes may exist for a prolonged duration of time, resulting in a delayed reversal or may not occur at all.

Cardiovascular involvement in PHPT patients may be as hypertension, left ventricular hypertrophy, diastolic dysfunction and valvular or myocardial calcification. Hedback et al. (9) have re- 
Table 3. Correlation of left ventricle dysfunction with serum PTH and serum calcium levels ( $n$ 30)

\begin{tabular}{|c|c|c|c|c|c|c|c|c|c|}
\hline & \multicolumn{2}{|c|}{$\begin{array}{l}\text { Ejection Fraction on MUGA } \\
\text { study }\end{array}$} & \multirow[b]{2}{*}{$p$} & \multicolumn{2}{|c|}{$\begin{array}{c}\text { Diastolic dysfunction on 2D } \\
\text { ECHO }\end{array}$} & \multirow[b]{2}{*}{$p$} & \multicolumn{2}{|c|}{$\begin{array}{l}\text { Diastolic dysfunction on } \\
\text { MUGA study }\end{array}$} & \multirow[b]{2}{*}{$p$} \\
\hline & $\begin{array}{l}>50 \% \\
(n 24)\end{array}$ & $\begin{array}{c}<50 \% \\
(n 6)\end{array}$ & & $\begin{array}{c}\text { Normal } \\
(\mathrm{n} 22)\end{array}$ & $\begin{array}{l}\text { Dysfunction } \\
\qquad(\mathrm{n} 8)\end{array}$ & & $\begin{array}{c}<180 \mathrm{~ms} \\
(\mathrm{n} \mathrm{17)}\end{array}$ & $\begin{array}{c}>180 \mathrm{~ms} \\
(\mathrm{n} \mathrm{13)}\end{array}$ & \\
\hline $\begin{array}{l}\text { Serum Calcium (mg \%) } \\
\left.\text { Median ( } 1^{\text {st }}\left|\mathrm{QR}, 3^{\text {rd }}\right| \mathrm{QR}\right)\end{array}$ & $\begin{array}{l}12(10.95 \\
13.60)\end{array}$ & $\begin{array}{c}11.68 \\
(11.20,12.34)\end{array}$ & 0.19 & $\begin{array}{c}12.1 \\
(11.5,13.27)\end{array}$ & $\begin{array}{c}11.35(10.67 \\
12.16)\end{array}$ & 0.66 & $\begin{array}{c}12 \\
(11.54,13.36)\end{array}$ & $\begin{array}{c}11.67 \\
(11.30,13.60)\end{array}$ & 0.37 \\
\hline $\begin{array}{l}\text { Serum PTH }(\mathbf{p g} / \mathbf{m l}) \\
\text { Median }\left(1^{\mathrm{st}}\left|\mathrm{QR}, 3^{\text {rd }}\right| \mathrm{QR}\right)\end{array}$ & $\begin{array}{c}1096.5 \\
(185,1735.75)\end{array}$ & $\begin{array}{c}756 \\
(201.5,1159)\end{array}$ & 0.24 & $\begin{array}{c}1018 \\
(169,1343)\end{array}$ & $\begin{array}{c}756 \\
(231.25,1773.5)\end{array}$ & 0.83 & $\begin{array}{c}405 \\
(161,1290.5)\end{array}$ & $\begin{array}{c}696 \\
(193,1291)\end{array}$ & 0.76 \\
\hline
\end{tabular}

ported increased cardiovascular deaths in 4461 PHPT patients with risk ratio of 1.71 among men and 1.85 in women. In the present study, hypertension improved in two of nine patients after PTx, subsequently they did not require anti-hypertensive medication. Improvement in blood pressure has been reported by various studies (10-12). However, there are reports in the literature where there is no improvement in blood pressure after PTx $(13,14)$.

$\mathrm{LVH}$, which is a significant predictor of cardiac morbidity and mortality in PHPT patients, was present on 2D ECHO in two patients in this study; which improved after six months of surgery by decrease in left ventricular wall thickness from $13 \mathrm{~mm}$ to 10 $\mathrm{mm}$ in both these patients. In a meta-analysis by Mc Maohnet al, 457 PHPT patients from 15 studies have been analyzed and they have reported that there was decrease in left ventricular mass by $12.5 \%$ six months after PTx (15). They have also hypothesized that PTH rather than calcium may be the casual factor leading to LVH in PHPT. On the contrary, there are reports in the literature where no significant regression of $\mathrm{LVH}$ is observed after 6-24 months of PTx $(13,16,17)$.

Left ventricular function is the most important factor for predicting cardiovascular morbidity in patients' with PHPT; and echocardiography is an easy, inexpensive, and non-invasive method. In this study, echocardiography was used for assessing the effect of PHPT on systolic and diastolic function; none of the patients showed systolic dysfunction on 2D ECHO as EF remained the same both pre and postoperatively. However, diastolic dysfunction was detected in eight patients and six of them showed improvement after PTx. In a recent meta-analysis by Best et al., echocardiogram changes after PTx in PHPT have analyzed, and they have concluded that there was no significant difference in left ventricular ejection fraction, diastolic dysfunction, IVST, and PWT pre and post- PTx (18). Nappi et al. have evaluated systolic and diastolic dysfunction by Doppler and M mode echo in patients with PHPT before and after PTx (17). They have reported LVH and significant impairment of LV diastolic function but only trivial impairment of LV systolic function; and after PTx there was no substantial improvement in structure and function even after attaining normocalcemia. Farahnak et al., in
51 PHPT patients, have also reported that systolic function (EF) on 2D ECHO stayed the same even after one year of PTx (19). On the contrary, Agarwal et al. have demonstrated left ventricular systolic function on 2D ECHO with significant improvement after six months of surgery $(p<0.001)(20)$.

MUGA study is a noninvasive diagnostic test which aids in accurate and reproducible evaluation of left ventricular ejection fraction in addition to assesses the diastolic dysfunction such as peak filling rate and time to peak filling rate. Assessment of ventricular function with $2 \mathrm{D}$ ECHO requires mathematical assumption about geometry of the ventricle and such assumptions work well only when ventricle shape is maintained. However, MUGA study results in higher reproducibility as there is no geometric assumption and has the advantage of being operator independent (21).

MUGA study documented systolic dysfunction (EF <50\%) in six patients pre-operatively whereas there was no systolic dysfunction on 2D ECHO in these patients. Hence, MUGA study provided a more objective assessment of cardiac function as compared to 2D ECHO. Similarly, MUGA study also documented diastolic dysfunction (tTPF $>180$ ms) in 43.33\% (n 13) PHPT patients in comparison to eight patients on 2D ECHO; with significant improvement in ten of these patients after surgery ( $p=$ 0.007). Whereas Stefenelli et al. (15), in 53 PHPT patients, have not observed any improvement in diastolic function by 2D ECHO over a 12 month follow-up. However, there are contradictory reports available in the literature showing improvement in diastolic dysfunction after PTx (20).

Cardiovascular involvement is still not considered as an indication for PTx despite the fact that PHPT is associated with increased cardiovascular morbidity and mortality. This may be based upon the variable incidence or presence of cardiovascular changes as mentioned in the literature. However, in this study, it was determined that MUGA study provided additional objective assessment of cardiac function in PHPT patients with demonstrable improvement in left ventricular function after PTx. Therefore, presence of cardiac dysfunction can be considered as one of the indications for surgical intervention. 


\section{Limitations}

In this study, both sample size and follow-up were small. Further randomized control trials with larger number of patients are required including both symptomatic and asymptomatic patients with PHPT to assess the changes in cardiac function at regular intervals over a longer period of time.

\section{CONCLUSION}

The present study compared pre- and post-operative cardiac function using both 2D ECHO and MUGA study in PHPT patients without any pre-existing cardiovascular co-morbidities. MUGA study provided a more objective assessment of cardiac function by determining left ventricular systolic and diastolic dysfunction. MUGA study is limited to academic centers only, which might be a prohibitive factor for its use.

Ethics Committee Approval: This study approval was obtained from Postgraduate Institute of Medical Education and Research (PGIMER) (Decision No: NK/4667/MS/731, Date: 27.03.2019).

Peer-review: Externally peer-reviewed.

Author Contributions: Concept - D.D.; Design - D.D.; Supervision - D.D.; Data Collection and/or Processing - K.A.; Materials - S.K.B., A.B.; Analysis and/ or Interpretation - A.S.; Writing Manuscript - D.D.; Critical Reviews - D.D., A.B.

Conflict of Interest: The authors have no conflicts of interest to declare.

Financial Disclosure: The authors declared that this study has received no financial support.

\section{REFERENCES}

1. Yeh MW, Ituarte PH, Zhou HC, Nishimoto S, Liu IL, Harari A, et al. Incidence and prevalence of primary hyperparathyroidism in a racially mixed population. J Clin Endocrinol Metab 2013; 98(3): 1122-9. [CrossRef]

2. Berger C, Almohareb O, Langsetmo L, Hanley DA, Kovacs CS, Josse $R G$, et al. Characteristics of hyperparathyroid states in the Canadian multicentre osteoporosis study (CaMos) and relationship to skeletal markers. Clin Endocrinol (Oxf) 2015; 82(3): 359-68. [CrossRef]

3. Shah VN, Bhadada S, Bhansali A, Behera A, Mittal BR. Changes in clinical \& biochemical presentations of primary hyperparathyroidism in India over a period of 20 years. Indian J Med Res 2014; 139(5): 694-9. [CrossRef]

4. Brown SJ, Ruppe MD, Tabatabai LS. The parathyroid gland and heart disease. Methodist Debakey Cardiovasc J 2017; 13(2): 49-54. [CrossRef]

5. Bilezikian JP, Brandi ML, Eastell R, Silverberg SJ, Udelsman R, Marcocci C, et al. Guidelines for the management of asymptomatic primary hyperparathyroidism: summary statement from the Fourth International Workshop. J Clin Endocrinol Metab 2014; 99(10): 3561-9. [CrossRef]

6. Bollerslev J, Rosen T, Mollerup CL, Nordenstrom J, Baranowski M, Franco $C$, et al. Effect of surgery on cardiovascular risk factors in mild primary hyperparathyroidism. J Clin Endocrinol Metab 2009; 94(7): 2255-61. [CrossRef]
7. Walker MD, Rundek T, Homma S, DiTullio M, Iwata S, Lee JA, et al. Effect of parathyroidectomy on subclinical cardiovascular disease in mild primary hyperparathyroidism. Eur J Endocrinol 2012; 167(2): 277-85. [CrossRef]

8. Persson A, Bollerslev J, Rosen T, Mollerup CL, Franco C, Isaksen GA et al. Effect of surgery on cardiac structure and function in mild primary hyperparathyroidism. Clin Endocrinol (Oxf) 2011; 74(2): 174-80. [CrossRef]

9. Hedback G, Oden A. Increased risk of death from primary hyperparathyroidism-an update. Eur J Clin Invest 1998; 28(4): 271-6. [CrossRef]

10. Schiffl H, Lang SM. Hypertension secondary to PHPT: Cause or coincidence? Int J Endocrinol 2011; 2011: 1-6. [CrossRef]

11. Brown J, de Boer IH, Robinson-Cohen C, Siscovick DS, Kestenbaum $B$, Allison $M$, et al. Aldosterone, parathyroid hormone, and the use of renin-angiotensin-aldosterone system inhibitors: the multi-ethnic study of atherosclerosis. J Clin Endocrinol Metab 2015; 100(2): 490-9. [CrossRef]

12. Broulik P, Brouliková A, Adámek S, Libanský P, Tvrdoň J, Broulikova K, et al. Improvement of hypertension after parathyroidectomy of patients suffering from primary hyperparathyroidism. Int I Endocrinol 2011; 2011: 309068. [CrossRef]

13. Dalberg K, Brodin L, Juhlin-Dannfelt A, Farnebo L. Cardiac function in primary hyperparathyroidism before and after operation. An echocardiographic study. Eur J Surg 1996; 162(3): 171-6. [CrossRef]

14. Salahudeen A, Thomas T, Sellars L, Tapster S, Keavey P, Farndon J, et al. Hypertension and renal dysfunction in primary hyperparathyroidism: effect of parathyroidectomy. Clinical Science 1989; 76(3): 28996. [CrossRef]

15. McMahon DJ, Carrelli A, Palmeri N, Zhang C, DiTullio M, Silverberg SJ, et al. Effect of parathyroidectomy upon left ventricular mass in primary hyperparathyroidism: a meta-analysis. J Clin Endocrinol Metab 2015; 100(12): 4399-407. [CrossRef]

16. Kepez A, Yasar M, Sunbul M, Ileri C, Deyneli O, Mutlu B, et al. Evaluation of left ventricular functions in patients with primary hyperparathyroidism: Is there any effect of parathyroidectomy? Wien Klin Wochenschr 2017; 129(9-10): 329-36. [CrossRef]

17. Nappi S, Saha H, Virtanen V, Limnell V, Sand J, Salmi J, et al. Left ventricular structure and function in primary hyperparathyroidism before and after parathyroidectomy. Cardiology 2000; 93(4): 229-33. [CrossRef]

18. Best CAE, KIN HBA, Krishnan R, Malvankar-Mehta S, MacNeil D. EChocardiogram changes following parathyroidectomy for primary hyperparathyroidism. Medicine 2017; 96(43): e7255. [CrossRef]

19. Farahnak P, Ring M, CaidahI K, Farnebo L, Eriksson M, Nilsson I. Cardiac function in mild primary hyperparathyroidism and the outcome after parathyroidectomy. Eur J Endocrinol 2010; 163(3): 461-7. [CrossRef]

20. Agarwal G, Nanda G, Kapoor A, Singh KR, Chand G, Mishra A, et al. Cardiovascular dysfunction in symptomatic primary hyperparathyroidism and its reversal after curative parathyroidectomy: results of a prospective case control study. Surgery 2013; 154(6): 1394-404. [CrossRef]

21. Mitra D, Basu S. Equilibrium radionuclide angiocardiography: Its usefulness in current practice and potential future applications. World J Radiol 2012; 4(10): 421-30. [CrossRef] 


\title{
ORIJINAL ÇALIŞMA-ÖZET
}

Turk J Surg 2021; 37 (4): 336-341

\section{Küratif paratiroidektominin sol ventrikül fonksiyonları üzerindeki etkisi 2D ECHO ve MUGA çalışması ile değerlendirildi}

\author{
Kishore Abuji ${ }^{1}$, Divya Dahiya ${ }^{1}$, Ashwani Sood ${ }^{3}$, Madan Parmar ${ }^{3}$, Sanjay Kumar Bhadada ${ }^{2}$, Rajesh Vijayvergiya ${ }^{4}$, Arunanshu Behera ${ }^{1}$ \\ ${ }^{1}$ Mezuniyet Sonrası Tıp Eğitimi ve Araşıırma Enstitüsü (PGIMER), Genel Cerrahi Anabilim Dalı, Chandigarh, Hindistan \\ ${ }^{2}$ Mezuniyet Sonrası Tıp Eğitimi ve Araşıırma Enstitüsü (PGIMER), Endokrinoloji Anabilim Dalı, Chandigarh, Hindistan \\ ${ }^{3}$ Mezuniyet Sonrası Tıp Eğitimi ve Araştırma Enstitüsü (PGIMER), Nükleer Tıp Anabilim Dalı, Chandigarh, Hindistan \\ ${ }^{4}$ Mezuniyet Sonrası Tıp Eğitimi ve Araştırma Enstitüsü (PGIMER), Kardiyoloji Anabilim Dalı, Chandigarh, Hindistan
}

\section{ÖZET}

Giriş ve Amaç: Primer hiperparatiroidizm (PHPT), artmış kardiyovasküler morbidite ve mortalite ile ilişkilidir ve paratiroidektomi (PT) sonrası kardiyovasküler değişikliklerin geri döndürülebilirliği ile ilgili çelişkili sonuçlara sahiptir. Bu çalışma, PHPT'li hastalarda hem yapısal hem de fonksiyonel kardiyak değişiklikleri ve bunların PT sonrası geri dönüşünü değerlendirmek için yapılmıştır.

Gereç ve Yöntem: Kardiyovasküler risk faktörleri bulunmayan 30 semptomatik PHPT hastası, ameliyattan önce ve küratif PT'den altı ay sonra 2D Ekokardiyografi (ECHO) ve Multigated Acquisition (MUGA) çalışması ile prospektif olarak değerlendirildi.

Bulgular: 30 hastanın dokuzunda hipertansiyon vardı ve ikisinde PT sonrası düzeldi ( 0 ,20). Preoperatif 2D ECHO'da sol ventrikül hipertrofisi olan iki hastada PT sonrası iyileşme görüldü ( $p<0,001)$. Sol ventriküler ejeksiyon fraksiyonu (EF), 2D ECHO'da PT'den önce ve sonra önemli bir değişiklik göstermedi. Oysa MUGA çalışmasında preoperatif $\mathrm{EF}<\% 50$ olan altı hastadan dördü sistolik disfonksiyonu temsil etmektedir; PT sonrası gelişme gösterdi. 2D ECHO'da sekiz hasta, küratif cerrahiden sonra altı hastada düzelen diyastolik disfonksiyon gösterdi ( $p=0,07)$. Bununla birlikte, MUGA çalışmasında, diyastolik disfonksiyona işaret eden tTPF (zirve dolum zamanına kadar geçen süre) >180 ms ile başvuran 13 hasta, on hasta PT sonrası iyileşme gösterdi $(p=0,008)$.

Sonuç: Bu çalışma, hem 2D ECHO hem de MUGA çalışmasını kullanarak preoperatif ve postoperatif kardiyak fonksiyonu analiz etti. MUGA çalışması, sol ventrikül ejeksiyon fraksiyonunu ve diyastolik disfonksiyonu belirleyerek kalp fonksiyonunun daha objektif bir değerlendirmesini sağlamıştır.

Anahtar Kelimeler: MUGA çalışması, birincil hiperparatiroidizm, sol ventrikül disfonksiyonu, 2D ekokardiyografi, paratiroidektomi, kardiyak belirtiler

Doi: $10.47717 /$ turkjsurg.2021.5167 